\title{
FILOZOFIJA I KURIKUL
}

\section{Raul Raunić}

Odsjek za filozofiju, Filozofski fakultet,

Sveučilište u Zagrebu, Hrvatska

rraunic@ffzg.hr

Rad čine tri povezana argumentacijska niza. Prvo, utvrđuju se osnovna deskriptivna i preskriptivna značenja te normativne povezanosti pojmova filozofije, odgojno-obrazovnog procesa i kurikula. Drugo, raščlanjuje se i kritizira metodički ustroj prevladavajućeg obrasca odgojno-obrazovnog kurikula sazdanog na znanstveno-tehnologijskoj $i$ menadžerskoj paradigmi, instrumentalno definiranim ciljevima te bihevioristički potvrđenim i mjerljivim ishodima učenja. Treće, obrazlaže se značaj kritičke, holističke i dugoročne filozofijske perspektive $i$ filozofijske refleksije u promišljanju odgojno-obrazovnog kurikula. Taj se značaj prvenstveno očituje u prepoznavanju slijepih putova. Sjedne strane, to su oni sačinjeni od isključivo instrumentalnih ciljeva i tehnologijskih redukcionizama. S druge strane, to su izravne svjetonazorske isključivosti koje u suvremeno doba vrijednosnog pluralizma svoje partikularne supstancijalne vrijednosti nastoje ideologijski nametnuti kao univerzalne.

Ključne riječi: filozofijska refleksija, odgoj i obrazovanje: normativno značenje i ciljevi, kurikul: povijest i pravci, kritika znanstveno-tehnologijskog i menedžerskog koncepta kurikula

Odnos filozofije i odgojno-obrazovnog kurikula načelno je moguće razmatrati na dvije povezane razine. Prvu razinu čini makro perspektiva s koje se postavlja pitanje o filozofiji odgojno-obrazovnog kurikula. S te razine propituju se temeljne svrhe odgoja i obrazovanja te načini kurikularne integracije obrazovnih procesa. Drugu razinu čini mikroperspektiva s koje se pak razmatraju pitanja predmetnog kurikula filozofije. S te razine utvrđuju se ciljevi, načini izvedbe i evaluacije 
nastavnog predmeta filozofije te njegova uloga u cjelokupnome odgojno-obrazovnom kurikulu (Raunić, 2011).

Moja je nakana u ovome radu kritički razmotriti prvu od navedenih razina. To podrazumijeva dva temeljna problema:

1) Utvrditi osnovna značenja i normativne veze između pojmova filozofije, odgojno-obrazovnog procesa te kurikula;

2) Pristupiti analizi i kritici metodičkog ustrojstva prevladavajućeg obrasca odgojno-obrazovnog kurikula sazdanog na znanstvenotehnologijskoj paradigmi, instrumentalno definiranim ciljevima te bihevioristički potvrđenim i mjerljivim ishodima učenja.

\section{Filozofija, odgoj i obrazovanje, kurikul: značenja i normativnosti}

Konceptualna analiza značenja pojmova filozofije, odgoja i obrazovanja te kurikula omogućava posredno definiranje navedenih pojmova te razotkrivanje njihovih logičkih, normativnih i vrijednosnih određenja. Osnovna ideja takvog pristupa jest uvjerenje prema kojemu značenje pojma ne sadrži samo deskriptivne, nego i preskriptivne odrednice. ${ }^{1}$ Shodno tome, konceptualna analiza nastoji utvrditi uvjete koji trebaju biti zadovoljeni da bi pojam bio ispravno primijenjen. Pri tome se konceptualna analiza razvija $u$ dva smjera. $S$ jedne, redukcijske strane, ona nastoji dospjeti do fundamentalne razine, koja u najopćenitijim i nekontigentnim određenjima, izražava bit pojmova. S druge, konektivne strane, konceptualna analiza hoće utvrditi ulogu koju navedeni pojmovi imaju u širim cjelinama smisla (Strawson, 1999). Oba pravca konceptualne analize dovode do implicitnih definicijskih određenja. Riječ je o leksičkim, stipulativnim i teorijskim definicijama navedenih pojmova. Leksička definicija podsjeća na uvriježene standarde, načine razumijevanja i primjene navedenih pojmova. Radi se o pozivu na tradicionalna određenja s kojih je moguće prosuditi suvremenu teoriju i praksu obrazovanja. Stipulativne definicije pak, kroz analizu pojmova, predlažu pojmovni instrumentarij koji izravno postavlja normativne i

${ }^{1}$ Takvo uvjerenje odbacuje oštru dihotomiju između činjenica i vrednota koju zagovaraju klasični empiristi i logički pozitivisti. Štoviše, takvo uvjerenje shodno tezama klasičnih pragmatista Jamesa i Deweya drži da je gotovo sve naše iskustvo prožeto vrijednostima, normativnosti i preskriptivnim zahtjevima (Putnam, 2002, 7-45). 
preskriptivne zahtjeve, a koji onda određuju primjerenu uporabu navedenih pojmova. Naposljetku, razina teorijskih definicija, postavlja navedene pojmove i njihov međusobni utjecaj u širi intelektualni, kulturni i socijalni kontekst.

Sve tri dimenzije neizravnog definiranja pojmova smjeraju k njihovim preciziranjima. To je važno zbog: a) stvaranja arhimedovske točke jer, u parafrazi poznata Heraklitova fragmenta prema kojemu je postojanje nepravde uvjet za ime pravde, moguće je, u analogijskoj inverziji, izreći da je ime ili pojam odgoja i obrazovanja uvjet bez kojeg ne bismo znali ni prepoznati ni izreći što to razlikuje puko uvježbavanje, instruiranje ili obuku od onoga što doista jest obrazovanje; b) stvaranja orijentacijske točke $\mathrm{s}$ koje je moguće kritizirati suvremene teorijske i praktičke trendove u odgoju i obrazovanju.

\subsection{Pojam filozofije}

Filozofija iskazuje egzistencijalnu potrebu čovjeka za rekonstrukcijom smisla. Ta potreba pak počiva na odmaknutosti ljudskog bića od izravne sraštenosti u neposrednostima života. ${ }^{2}$ Takva odmaknutost ili distanca, koja se pokazuje u zbunjenosti, čuđenju, sumnji i udivljenju potiče procese djelovanja i mišljenja. U činu mišljenja čovjek se izdvaja iz svijeta te svijet i samog sebe čini predmetom - pred mene stavljenim objektom - svojih razmatranja. ${ }^{3}$ Takva razmatranja o nama samima i našemu svijetu - mislim i znam da mislim i djelujem - čine mišljenja drugog ili višeg reda odnosno stajalište samosvijesti ili refleksije. Filozofsko mišljenje je refleksivno, a refleksija je uz čitanje i pisanje te računanje, treći temeljni kod kulture. Predmete filozofskog mišljenja čine najopćenitiji i najapstraktniji problemi. Filozofija njima pristupa s:

${ }^{2}$ Tu ljudsku poziciju odmaknutosti minuciozno analizira Helmuth Plessner i određuje svojim poznatim iskazom - ekscentrična pozicionalnost čovjeka. »Ako je život životinje centričan, život čovjeka je, iako ne može probiti to centriranje, istovremeno izvan njega, ekscentričan. Ekscentričnost je za čovjeka karakteristična forma njegove postavljenosti prema okolini« (Plessner, 1981, 357).

${ }^{3}$ »Kao Ja, koje omogućuje pun okret živog sistema nazad prema sebi, čovjek više nije u onom Ovdje-Sada, već 'iza' njega, iza sebe samog, bez mjesta, u nečem, nestaje u tom ničem, u prostorno-vremenskom Nigdje-Nikad. Bezmjesno-bezvremenski on omogućava doživljaj svoje bezmjesnosti i bezvremenosti, kao stajanje izvan sebe samog, jer čovjek je živa stvar, koja više nije u sebi samoj, već čije 'stajanje u sebi' znači fundament njegova stajanja (Plessner, 1981, 357). 
a) pitanjima koja sadrže refleksivnu općost ili upućenost na bit predmeta;

b) temeljnim i okvirnim pitanjima koja osvještavaju pretpostavke problema i njihovo mjesto u široj slici svijeta;

c) konceptualnim pitanjima koja se tiču naših pojmova, njihova međusobnog odnosa i svijeta koji predstavljaju (Williams, 1985).

Razumljivo je da filozofija nije jedina koja nastoji rekonstruirati smisao i osvijestiti temeljna ljudska pitanja. To čine mitovi, religije, tradicije i različita svjetonazorska i moralna učenja. Filozofija, međutim, nastoji zadovoljiti visoke kriterije racionalnosti, uvjerljivosti i kritičnosti. Od njezinih se postavki očekuje da budu poduprte opravdanim i prihvatljivim razlozima te otvorene stalnom slobodnom propitivanju i samopropitivanju. U formalnom smislu to znači da filozofske tvrdnje i teorije trebaju zadovoljiti sljedeće kriterije: a) poštivati logičke i intelektualne standarde valjanog mišljenja; b) pokazati osjetljivost na kontekst; c) pružiti konceptualnu jasnoću koja otklanja nedorečenosti i višeznačnosti; d) otkloniti proturječne tvrdnje uključivši i autoreferentne nekonzistentnosti; e) uzimati načelno u obzir kompatibilnost ili usklađenost s dobro utvrđenim činjenicama i teorijama, odnosno težiti k refleksivnom ekvilibriju; ${ }^{4}$ f) smjerati k racionalnom koherentizmu koji nastoji sustavno i uvjerljivo povezati pojedine dijelove filozofskog mišljenja; g) kritički propitivati i graditi argumentaciju koja je kontinuirano izložena kritičkom sudu stručne i znanstvene javnosti, kao i autokorektivnim postupcima; $h$ ) koristiti različite argumentacijske strategije: od logičko znanstvenih do genealogijskih, koje razmatraju povijesni razvoj kulturnih tvorbi ${ }^{5}$ odnosno do obrazlaganja na način neformalne logike, kao što je primjerice abdukcija ili zaključivanje prema objašnjenju koje je u odnosu na druge najuvjerljivije.

Poseban problem u suvremenom dobu čini odnos između znanosti i filozofije. U središtu problema je scijentistički redukcionizam mo-

\footnotetext{
${ }^{4}$ Metodički i heuristički postupak refleksivnog ekvilibrija u praktičkoj filozofiji označava postupak promišljenog prosuđivanja i usklađivanja nekog stava s našim dosadašnjim uvjerenjima i načelima. Pri tome postupak promišljenog prosuđivanja u svrhu postignuća konzistentnosti i opravdanja naših uvjerenja ili odbacuje novi stav ili revidira naša dosadašnja uvjerenja i načela. Vidi: Rawls, 1999.

${ }^{5}$ Bernard Williams tako ustvrđuje: »Genealogija je narativ koji nastoji objasniti kulturni fenomen tako što opisuje način na koji je on nastao, ili mogao nastati ili je moguće zamisliti da je tako nastao« (Williams, 2002, 20).
} 
derne znanosti. On se ogleda u: a) izjednačavanju valjane spoznaje s usko shvaćenim znanstvenim znanjem; b) svođenju teorije spoznaje na teoriju znanosti; i c) stvaranju privida metateorijskog samorazumijevanja znanosti (Habermas, 1978). Sva tri aspekta upućuju na gnoseološki imperijalizam suvremene znanosti. Gotovo svaka spoznaja nastoji se strukturirati po modelu tehnologijske primjenjivosti znanja. Znanost, međutim, ne može reflektirati samu sebe. U povijesnoj genezi i logici pojma znanosti, filozofija je bila ta koja je određivala što je znanost, koji su njezini kriteriji, svrhe i na koncu granice. Riječju, filozofska refleksija znanosti čini ono što znanost sama ne može, a radi se o: a) propitivanju i utvrđivanju epistemoloških uvjeta i okvira znanosti koji utvrđuju kriterije valjanosti i pouzdanosti spoznaje; b) etičkoj refleksiji znanosti koja pita o njezinim svrhama - treba li se i zašto doista činiti ono što je znanstveno-tehnologijski moguće i izvedivo. Svaka kritika filozofije s reduciranog i strogo znanstvenog stajališta načelno je promašena jer se radi o drukčijoj vrsti diskursa. Znanstvena teorija, pa onda i znanstvena kritika filozofije, bilo osviješteno ili neosviješteno, pretpostavlja određena metafizička, gnoseološka i etička, dakle filozofijska uporišta. Suvremena znanost tako nastoji sebi priskrbiti autolegitimirajuće samorazumijevanje u korisnosti i učinkovitosti. No, filozofska pitanja tek tu počinju. Što je to i zašto vrijedno u korisnosti? Za koga je to korisno i u kojim segmentima života? Kako se ta korist odnosi prema drugim vidovima dobrog života? Kakve su posljedice isključive orijentacije na kratkoročne i individualistički definirane koristi, a obzirom na dugoročnu kvalitetu života i život drugih bića na Zemlji? Riječju, s filozofskom refleksijom, povezujemo naša različita iskustva i stječemo uvid nad cjelinom.

Kada je o odgojnim i obrazovnim znanostima riječ, filozofska refleksija ocrtava značenje i smisao pojmova odgoja i obrazovanja te kritički propituje prikrivene ili prešućene pretpostavke teorija i praksi edukacije.

\subsection{Pojam odgoja i obrazovanja}

Središnji značaj odgoja i obrazovanja ${ }^{6}$ za oblikovanje ljudskog identiteta proizlazi iz povijesne otvorenosti i nedovršenosti ljudske

\footnotetext{
${ }^{6}$ Cjeloviti pedagogijski proces interaktivnog i dinamičkog oblikovanja i samooblikovanja personalnog, socijalnog i kulturnog identiteta osobe u većini europskih jezika označava
} 
prirode. U procesima učenja, kako na filogentskoj razini - evoluciji društva ili povijesti roda, tako i na ontogenetskoj razini - konstitucije osobe ili genezi jastva - čovjek izgrađuje sebe s razvojem radnih, jezičnih, spoznajnih i moralnih sposobnosti i dispozicija. Pri tome se geneza jastva ili subjektivne svijesti očituje u procesima razgraničenja prema vanjskoj prirodi, normativnosti socijalnog svijeta te intersubjektivnosti jezika (Habermas, 1986, 140-186). Racionalizacija socijalnih praksi u evoluciji društva i razvoju pojedinca, kako to uvjerljivo pokazuje Habermas, očituje se u dva temeljna i međusobno nesvodiva djelovanja. Prvo je svrhovito racionalno djelovanje. Ono se manifestira u empirijski i tehnički provjerenim izborima sredstava i učinkovitostima realizacije zadanih ciljeva. Drugo je komunikativno djelovanje. S učenjem komunikativnog djelovanja osoba stječe sposobnost eksplikacije te unutarnje konzistentnosti svojih vrednota i načina djelovanja. Procesi racionalizacije komunikativnih sposobnosti očituju se u prihvaćanju univerzalističkih normativnih struktura. One omogućuju osobi da na temelju iskrenosti njezinih intencija, ispravnosti jezičnih iskaza te istinitosti reprezentiranih sadržaja postavlja valjane zahtjeve, ulazi u horizonte razumijevanja i postiže dogovor (Habermas, 1975).

Normativni pojam ljudske prirode, koji uključuje sposobnosti svrhovito racionalnog ili strategijskog djelovanja upućenog na uspjeh i sposobnosti komunikativnog djelovanja ili intersubjektivne umnosti upućene na dogovor, nezaobilazan je konceptualni temelj pojma odgoja i obrazovanja. Bez eksplicitnih i koherentnih stavova o ljudskoj prirodi, na koje se pojam odgoja i obrazovanja može referirati, on neminovno gubi supstancijalno i normativno značenje te ostaje samo na instrumentalnim i deskriptivnim konotacijama. Takav ogoljeni pojam odgoja i obrazovanja, bilo svjesno ili nesvjesno, pretpostavlja tek mehaničko viđenje ljudske prirode kao potencijalnog nositelja skupa uporabivih i primarno ekonomski isplativih vještina.

se pojmovima izvedenim iz latinskog glagola educare, u značenju odgojiti, podići odnosno imenice educatio, -onis $f$. Tako je engleska riječ education, francuska éducation, a talijanska educazione. U hrvatskom jeziku cjelovitost toga pedagogijskog procesa označava se zbirnom riječi odgoj $i$ obrazovanje. Nerazdružive sastavnice te riječi često se u suvremenoj jezičnoj uporabi oposebnjuju na taj način da se odgojni procesi vezuju uz stjecanje moralnih, karakternih i estetskih sposobnosti, dok se obrazovanje vezuje uz stjecanje intelektualnih sposobnosti i radnih vještina. Mehaničko razdvajanje tih dvaju sastavnica te globalno prisutno potiskivanje odgoja za korist instrumentalno shvaćenog obrazovanja uvjerljivo svjedoči o krizi našega vremena. 
Teorija i praksa edukacije, unatoč sve većoj parcijalizaciji znanja, dužna je, pa makar i okvirno, položiti račun o svom konceptualnom utemeljenju. Time se razotkrivaju dvije povezane stvari. Prva je način na koji se razumiju odgojni i obrazovni pojmovi te način njihove sistemske povezanosti. Druga stvar je filozofsko opravdanje ili etička legitimacija izabranih profila edukacijske teorije i prakse. Obje navedene stvari - filozofska analiza i legitimacija - stvaraju normativni plato s kojeg se utvrđuju intrinzične svrhe obrazovanja i postavljaju kriteriji edukacijskog djelovanja.

Što bi taj normativni plato pojma odgoja i obrazovanja - omeđen njegovim značenjima i vrednotama - zapravo sadržavao? Prvo, odgoj i obrazovanje je samosvrhovita vrednota. On može i treba biti koristan za mnoge stvari, ali njegova je primarna vrijednost što omogućava kognitivni, jezični i socijalni identitet čovjeka. Povijesni procesi učenja u najširem smislu riječi omogućavaju razvoj ljudskog roda. Štoviše, odgoj i obrazovanje nam je iskonski potreban baš kao što su to voda, hrana ili zdravlje te je izvor unutarnjeg zadovoljstva i ljudskog načina života.

Drugo, odgoj i obrazovanje rekonstruira različite vrste naših iskustava, omogućava veći nadzor nad njima, te proširuje naše kapacitete učenja. ${ }^{7}$ Odgoj i obrazovanje svagda unosi i refleksivnu svijest ili pitanje zašto je nešto takvo kakvo jest? Ono nas iz svijeta nerefleksivne danosti i predrasuda izvodi pred obvezujuću snagu razloga i odgovornosti.

Treće, odgoj i obrazovanje nadilazi puke instrukcije ili poznavanje vrlo uskog skupa činjenica i njihovih kauzalnih i/ili funkcionalnih povezanosti. Odgoj i obrazovanje ne zastaje na znanju o tome kako se nešto zbiva, nego zahtijeva i odgovore na pitanja s kakvim se pretpostavkama nešto zbiva, zašto, i u kojemu kontekstu. Odgoj i obrazovanje omogućava da iza poznavanja pravila, koja se tiču fenomenološke ravni i segmenata ljudskog života, steknemo uvide u principe te time ovladamo promjenjivim i kontingentnim uvjetima života (Peters, 2010, $1-17)$.

Četvrto, odgoj i obrazovanje je svagda inicijacija u različite forme znanja i vrednota. Pri tom, on istodobno stvara široke kognitivne perspektive i vrijedne forme života. One podrazumijevaju ne samo proširenje naših sposobnosti shvaćanja prirodnog svijeta nego i naše

${ }^{7}$ U takvom konceptualnom obzoru valja tražiti i odgovor na pitanje što je krajnja svrha odgoja i obrazovanja. Usp. Putnam, Hilary i Putnam, Ruth Anna (1994, 221-241). 
sposobnosti stvaranja i razumijevanja ljudskog svijeta i poopćenja volje. Obrazovanje je po definiciji opće i način je uvođenja čovjeka u zajednički svijet prožet normativnim strukturama i intersubjektivnim priznanjima.

Peto, odgoj i obrazovanje podrazumijeva i samosvijest o otvorenosti i povijesnosti edukacijskih vrednota i načela. Utoliko on uključuje i stavove kritičkog mišljenja i razboritog skepticizma. Nijedan relevantni aspekt ljudskog života, pa onda ni odgoj i obrazovanje, nisu od toga izuzeti.

Riječju, odgoj i obrazovanje stvara dubinske strukture razumijevanja koje na individualnoj i društvenoj razini omogućavaju ljudske forme života. Njih čine kontinuirani i široki procesi učenja i samooblikovanja. Utoliko je odgoj i obrazovanje doista ono što mi jesmo ili mi jesno ono što su nam procesi odgoja i obrazovanja omogućili da budemo.

\subsection{Pojam kurikula}

Obrazovni kurikul je sistemski okvir formalnog učenja i poučavanja koji preskripcijski utvrđuje: a) odgojne i obrazovne ciljeve te njihovu legitimaciju; b) sadržaj ili predmete poučavanja i njihovo opravdanje; c) metode i procedure poučavanja i školskih interakcija te legitimaciju edukacijskih autoriteta i uloge nastavnika i učenika; d) načine evaluacije ili prosudbe uspješnosti školskih interakcija i implementiranosti kurikula. ${ }^{8}$ Riječju, kurikul treba propisati ne samo ciljeve, sadržaje, metode edukacijskih interakcija, te načine provjere uspješnosti cijelog projekta, nego treba i opravdati normativna rješenja koja zagovara. Utoliko, pored važnih pitanja: kuda, što i kako, temeljno pitanje kurikula je i zašto ili čemu. To pitanje otvara problem prijeko potrebne legitimacije i samih pretpostavki, smisla i svrha kurikula. Opravdanja trebaju uvjerljivo pokazati prednosti predloženih rješenja pred alternativama i to u holističkoj perspektivi cjeline individualnog i društvenog života.

${ }^{8}$ Osnovne elemente koje treba sadržavati kurikul, ali bez njihova opravdanja budući da je vjerovao u autolegitimacijsku snagu znanstvene učinkovitosti, naznačio je još 1949 . Ralph Tyler kroz četiri pitanja: »1. Koje edukacijske ciljeve treba škola nastojati postići? 2. Koja edukacijska iskustva treba pružiti da bi se moglo postići te ciljeve? 3. Kako bi se ta edukacijska iskustva mogla učinkovito organizirati? 4. Kako je moguće odrediti jesu li ti ciljevi postignuti?«, Basic Principles of Curriculum and Instruction, navedeno prema Kelly, Vic A. $(2009,20)$. 
Ishodišni poticaji za kurikulno planiranje i ustrojavanje školskih interakcija nastali su sa snažnim pragmatičkim zaokretom u zapadnoj kulturi s početka prošloga stoljeća. Taj je trend, potaknut i podržan privrednim promjenama - snažnim valovima industrijalizacije i masovnim useljavanjem - kao i masovnim školstvom i širenjem instrumentalne racionalnosti u sva područja života, osobito izražen u SAD, gdje je i najrazvijenija teorija i praksa kurikulnog ustrojstva školstva. Razlozi koji se uobičajeno navode za kurikulni ustroj školskih interakcija, a koji treba zamijeniti tradicionalnu orijentaciju na nastavne sadržaje i programe, ${ }^{9}$ su sljedeći:

1) Potrebno je prevladati raskorak između školskih znanja i iskustava $\mathrm{s}$ jedne te životnih i radnih potreba pojedinaca i društva $\mathrm{s}$ druge strane. Tradicionalna školska znanja najčešće nisu izravno uporabiva, nego zahtijevaju daljnja posredovanja, a da bi se pokazala korisnim u radnim i životnim situacijama. Utoliko se, s kurikulnim pomakom, od nastavnih sadržaja na nastavne ciljeve, od stjecanja znanja do iskazivanja mjerljivih postignuća, nastoji izravnije, funkcionalnije i korisnije povezati školsko obrazovanje s aktualnim potrebama privrednog života.

2) Kurikulni ustroj orijentiran na iskazivanje korisnih i mjerljivih postignuća $i$ ishoda omogućava, tvrdi se, nadilaženje predmetnih ograničenja, bolju transverzalnu povezanost te snažniju integraciju i koherentnost.

3) Kurikulni ustroj, s listom precizno određenih, jasno razdijeljenih, bihevioristički uočljivih i mjerljivih učinaka i ishoda omogućava veći nadzor i predvidljivost odgojno-obrazovnih procesa te izraženije kapacitete raspoloživosti i intervencija.

\footnotetext{
${ }^{9}$ Pojam kurikula u širem smislu riječi obuhvaća svaki oblik planiranja i ustrojstva odgojno-obrazovnih interakcija pa utoliko i tradicionalne edukacijske koncepcije orijentirane na nastavne sadržaje i programe čine jednu od mogućih inačica kurikula. Takva uporaba riječi prevladava u anglosaksonskom govornom području u kojem je kurikulno planiranje oduvijek bilo prevladavajući način reflektiranja odgojno-obrazovnih procesa. U europskoj kontinentalnoj tradiciji pak, u kojoj postoji duga i utjecajna tradicija didaktičkih promišljanja, pojam kurikula, uvezen iz drugih kulturnih tradicija, do sada se uobičajeno koristio u užem značenju. Ono podrazumijeva planiranje i ustrojstvo odgojno-obrazovnih procesa koje ističe prvenstvo nastavnih ciljeva i ishoda pred sadržajima i metodama te snažniju integriranost, predvidljivost i nadzor nad edukacijskim procesima. U tom užem smislu riječi, pojam kurikula koristi se i u domaćoj znanstvenoj i stručnoj literaturi. Štoviše, pojam kurikula u tom užem značenju riječi suprotstavlja se dosadašnjoj koncepciji obrazovanja utemeljenoj na nastavnim sadržajima i programima. Tako se, primjerice, u dokumentu Nacionalni okvirni kurikulum (MZOS, 2011, 13) ističe da je »kurikulum širi i dublji od nastavnog plana i programa«.
} 
U povijesti kurikulnog oblikovanja odgojno-obrazovnih procesa iznjedreni su brojni i suprotstavljeni modeli. Oni se ipak, u gruboj, idealno-tipskoj metodologiji, mogu svesti na dvije osnovne paradigme: tzv. znanstvenu i humanističku. Znanstvena paradigma objedinjuje niz sličnih kurikulnih modela koji metodologiju prirodnih znanosti i kanone instrumentalne racionalnosti izravno primjenjuju na područje odgojnoobrazovnih interakcija. Humanistička paradigma pak, obuhvaća različite, pa i međusobno suprotstavljene modele, koje ipak povezuje uporište u normativnom pojmu ljudske prirode i uvažavanje komunikacijskog ili intersubjektivnog tipa racionalnosti. Znanstvena paradigma, shodno instrumentalnoj racionalnosti, čini ciljno usmjereni pristup, usredotočen na precizno definiranje ishoda i iznalaženje učinkovitih sredstava. Ciljevi i ishodi su gotovo isključivo utilitarno legitimirani tržišnom konkurentnošću radne snage ili privrednom koristi. Humanistička paradigma, za razliku od toga, nastoji sačuvati i dimenziju intrinzične vrijednosti odgojno-obrazovnog procesa. Ona se ogleda u samosvrhovitim edukacijskim vrednotama i principima, koji usmjeravaju kultiviranje i razvoj sposobnosti osobe kroz intersubjektivne i samosvrhovite forme jezičnih, socijalnih, kognitivnih, voljnih, estetičkih, psiho-motoričkih i drugih inicijacija.

Znanstvena paradigma, oboružana tehnologijskom racionalnosti tvornice obrazovanja, opravdava svoje postavke s učinkovitim modifikacijama iskoristivih aktivnosti i ponašanja učenika. Te neposredno iskoristive aktivnosti, proklamirane obrazovnim ciljevima i ishodima, a proizvedene procesom obrazovanja, utvrđuju se i mjere biheviorističkim opservacijama. Shodno input-output logici instrumentalne racionalnosti, učinkovitost je svedena na kvantitetu ciljano uzrokovanih promjena ponašanja učenika u jedinici vremena. Stupanj učinkovitosti kvantitativnih promjena utvrđenih objektivnim mjerilima, pokazuje, prema znanstvenoj paradigmi, onda i kvalitetu obrazovanja.

Prva moderna razilaženja između znanstvene i humanističke paradigme u konstrukciji kurikula zbivaju se u prvim desetljećima prošlog stoljeća. Pragmatički zaokret u modernoj kulturi doveo je do dva različita stajališta u polju obrazovanja. Prvo je, pleonazmom iskazano, tehnološka pragmatičnost i znanstveni pragmatizam. To stajalište ustrojava školski kurikul prema obrascima i uvidima industrijske psihologije 
i opće teorije upravljanja. Pionirsko djelo Franklina Bobbitta Kurikul iz 1918., unatoč kasnijim pomacima od »zatvorenog « k »otvorenom《 kurikulu, rodno je mjesto tzv. znanstveno utemeljenog kurikuluma (Kliebard, 2004). Obrazovanje je tu primarno shvaćeno kao učinkovita proizvodnja socijalno i ekonomski korisnih bihevioralnih promjena, prethodno zadanih listom očekivanih i mjerljivih ishoda.

Drugi odgovor teorije na kulturni zaokret prema pitanjima životne prakse je stajalište filozofijskog pragmatizma. Njega zastupa John Dewey, koji se, s jedne strane, suprotstavlja tradicionalnim stajalištima Johanna Fredricha Herbarta i njegovih sljedbenika za koje je interes učenika u središtu obrazovanja, i, s druge strane, još i starijim nazorima o samosvladavanju i mentalnoj disciplini kao ishodištu obrazovanja, koji u Europi propagiraju još Christian Wolff, Immanuel Kant, a u Americi William Harris (Kliebard, 2004). Dewey pak u središte školske interakcije postavlja problemsku situaciju. Kao pragmatist, Dewey inzistira na praktičnosti znanja jer znanje nije kontemplativna distanca prema svijetu, nego način djelovanja u svijetu. Humanističku jezgru Deweyeva pragmatizma čine pak sljedeće točke:

a) škola nije puki servis društva, nego je pokretač moralnog, socijalnog i političkog napretka;

b) odgoj i obrazovanje treba omogućiti svakom učeniku da razvije i ovlada svim svojim sposobnostima te bude spreman djelatno odgovoriti na izazove budućnosti;

c) školstvo osposobljava pojedinca za stjecanje samosvojnog identiteta u socijalnoj interakciji i demokratskoj političkoj kulturi (Dewey, 1916; Ryan, Alan, 1988, 394-410).

Humanistička paradigma nakon Deweya razvija se u mnoštvo međusobno različitih pravaca i područja interesa (Scott, 2008). Bez obzira na velike međusobne razlike zajedničko im je protivljenje spram znanstveno-tehnologijskog modela obrazovanja. Teorijski najutjecajnija stajališta humanističke paradigme su: liberalni fundacionizam Richarda S. Petersa (Peters, 1967; 1978) i Paula Hirsta (Hirst, 1971), socio-kulturna teorija učenja i narativna konstrukcija kurikula Jerome Brunera (Bruner, 1977; 2000), kritička pedagogija Henry Giroux (Giroux, 1977; 2005), refleksivna praksa Donalda Schöna (Schön, 1983), autonomija i ispunjeni život Johna Whitea (White, 2010), demokratski odgoj Amy Gutmann (Gutmann, 1999). 


\section{Kritika znanstveno-tehnologijskog i menadžerskog modela kurikula: je li škola doista isto što i tvornica?}

Početak prevlasti znanstveno-tehnologijski i menadžerski ustrojenog kurikuluma započinje osamdesetih godina prošlog stoljeća s usponom konzervativnih politika deregulacije: Margaret Thatcher u Velikoj Britaniji i Ronalda Reagana u SAD. Na valovima globalizacije i međunarodne ekonomske konkurentnosti doktrine tačerizma i reganizma $\mathrm{u}$ polju obrazovnih strategija, proširile su se devedesetih godina na jugoistok Azije, prije svega na Hong Kong, a u prvom desetljeću 21. stoljeća na ostatak Europe. Sociološka i politološka analiza takvih obrazovnih strategija nije u prvome planu moga pristupa. Dostatno je tek spomenuti da je pod krinkom osuvremenjivanja i racionalizacije pokrenuta demontaža socijalne države i to tako da je u polju obrazovanja stvoren novi koordinatni sustav. Na njegovoj apscisi zacrtano je odstupanje od obrazovanja kao javnog dobra i njegovo postupno potiskivanje u sferu privatno pravnih inicijativa, odgovornosti i napose financiranja. $\mathrm{Na}$ njegovoj ordinati pak zacrtana je izravna, ničim posredovana i maksimalna funkcionalna prilagodba tržištu radne snage i drugim naplativim interesima i potrebama. Obrazovanje je time svedeno na samo i jedino zavisnu varijablu bez vlastitog subjektiviteta. ${ }^{10}$

Takav tektonski pomak doveo je do napuštanja normativnog pojma odgoja i obrazovanja, a time i njegovih imanentnih preskriptivnih zahtjeva. Preostao je samo deskriptivni i instrumentalizirani pojam obrazovanja. On je u potpunosti sveden na kontroliranu implementaciju atomiziranih podciljeva, a u svrhu maksimalističkih zahtjeva logike kapitala. Pomak se očituje u dvije velike promjene.

Prva je formalne i institucionalne naravi. Na mjesto organizacije Ujedinjenih nacija UNESCO-a (United Nations Educational, Scienti-

${ }^{10}$ Osnovna ideja u takvoj instrumentalizaciji odgoja i obrazovanja i nije posve nova. U drugoj polovici sedamdesetih godina Stipe Šuvar inicirao je reformu školstva u Republici Hrvatskoj pod nazivom usmjereno obrazovanje. Smjer takvog obrazovanja bio je strogo funkcionalno podvrgavanje onodobnim radnim mjestima. Šuvarove zablude, iznesene u programskoj knjizi Škola i tvornica: u susret reformi odgoja i obrazovanja, Zagreb: Školska knjiga, 1977, danas, mutatis mutandis, potencirano oživljavaju s novim subjektima: sveukupno školstvo (uključujući i visoko obrazovanje) i korporacije. To što takve ideje dolaze iz Europe, a u Europu iz Amerike, nažalost čini da se nedovoljno kritički prihvaćaju, među ostalima i u aktualnome prijedlogu Cjelovite kurikularne reforme iz 2016. Prevladavajuće trendove u odgoju i obrazovanju svakako nije moguće ignorirati, ali dominacija u trendu ne znači istodobno i legitimaciju. O kritici Šuvarove reforme obrazovanja vidi Raunić, 1988. 
fic and Cultural Organization) koja jedina ima međunarodni autoritet i mandat u pitanjima odgoja i obrazovanja, stupaju organizacije proizašle iz ekonomskih interesa, kao što su OECD (Organisation for Economic Co-operation and Development). Ta međunarodna organizacija za ekonomsku suradnju i razvoj vođena dugoročnom logikom kapitala, kroz svoje posebne i financijski obilato potpomognute programe, kao što su projekt PISA (Programme for International Student Assessment) svake tri godine testira osnovne učeničke sposobnosti petnaestogodišnjaka u matematici, znanosti i čitanju s razumijevanjem. Objedinjujuća točka i snažan naglasak svih testova je na primijenjenim, kalkulirajućim i upravo poduzetničkim kompetencijama i ishodima instrumentalne racionalnosti. To je, u najboljem slučaju, ipak samo dio obrazovnih ciljeva. Nakon PISA testova, koji za sebe samouvjereno tvrde da "procjenjuju kvalitetu, pravičnost i učinkovitost školskih sustava« stvaraju se jedinstvene rang liste uspješnosti zemalja i podupiru globalizacijski procesi. Događaji su praćeni medijskim i drugim vrstama pritisaka, raznim agencijama i odborima koji nesebično nude svoje usluge $u$ otklanjanju zbiljskih ili tek prividnih manjkavosti te s međunarodnim fondovskim mamcima, a sve u svrhu žurnih restrukturiranja domicilnih obrazovnih strategija, shodno, dakako, konceptu obrazovanja i prikrivenom kurikulu ideologa PISA testiranja. ${ }^{11}$

Sve to, naravno, ne znači da su domicilne obrazovne strategije a priori dobre. Puno je vjerojatnije, baš kao što je to i u Hrvatskoj, da su obrazovni sustavi u vremenu brzih događanja i teško predvidivih zbivanja u globaliziranom svijetu, zreli za reformu. Prava su pitanja, međutim, kakve su promjene potrebne, s kojim razlozima i u čijem interesu, tko ih i kako treba odrediti i provesti te koje su izravne i neizravne posljedice reformi na osobnom, socijalnom, kulturnom i političkom planu.

${ }^{11}$ Nasuprot institucionalnoj i medijskoj promociji PISA testova, kritički tonovi mnogo teže dopiru do javnosti. Na tom planu valja istaknuti otvoreno pismo stotinjak uglednih profesora i akademika odgojnih i obrazovnih znanosti širom svijeta koji su u svibnju 2014. uputili otvoreno pismo dr. Andreasu Schleicheru, direktoru OECD-ova projekta PISA, u kojemu argumentirano ukazuju na to da takva vrsta testiranja i rangiranja zapravo osiromašuje i osakaćuje obrazovanje te šteti široko prihvaćenim načelima dobrog odgoja i demokratskih praksi. Vidi: The Guardian, 6 May 2014, »OECD and PISA tests are damaging education worldwide - academics«. Tu je i nadahnuta knjiga Konrada Paula Liessmanna (2008), Teorija neobrazovanosti: Zablude društva znanja, Zagreb: Naklada Jesenski i Turk, koja u stilu Andersenova Careva novog ruha razotkriva što se krije iza fenomenologijske ravni suvremenih obrazovnih reformi. 
Druga vrsta dalekosežnih promjena koja nastaje s napuštanjem normativnog koncepta i prakse odgoja i obrazovanja unutarnje je i sadržajne naravi. S njome ne samo što su odgoj i obrazovanje posve $\mathrm{i}$ isključivo podvrgnuti privrednim i tržišnim ciljevima, nego i same odgojne i obrazovne institucije po svojem unutarnjem ustrojstvu i načinu djelovanja postaju prave tvornice znanja. Ta se preobrazba očituje u barem tri stvari:

a) Opći menadžerski koncept upravljanja preuzet iz područja poslovne ekonomije i vođen isključivo instrumentalnom racionalnošću kratkoročnih cost-benefit analiza stupa na mjesto pedagoške komunikacije i nastavnog dijaloga. Taj interesno motivirani quid pro quo postavlja tehnički obrazac svrhovitoracionalnog djelovanja upućenog na uspjeh i učinkovitost na mjesto komunikativnog djelovanja ili simboličke interakcije upućene na dogovor i izgradnju horizonata razumijevanja. U složenosti i slojevitosti odgojno-obrazovnog procesa razumljivo je da svakoj vrsti djelovanja: svrhovito-racionalnog i komunikativnog treba dati njemu pripadajuću ulogu. Problem s tzv. znanstvenim kurikulom je što se komunikacija sustavno potiskuje na ime jednosmjernoga tehničkog proceduralizma koji smjera k tome da učinkovito i apriorno priredi i nadzire svaku nastavnu situaciju.

b) Fundamentalno različite forme znanja, umijeća i sposobnosti (Hirst, 2010, 41-52) nasilno se svode na jedinstveni tehnologijski mega-obrazac ishoda učenja koji počiva na atomizaciji sadržaja, strogom linearnom proceduralizmu te preciznoj kontroli pokreta, prostora, vremena i svakog djelića izvedbe. Nije stoga čudno što su stvoreni pravi univerzalni priručnici (Kennedy, 2006) koji upućuju na to kako sadržaje i ciljeve poučavanja prevesti na univerzalni jezik ishoda učenja. Pri tome se za svaku mehanički razdvojenu razinu i vrstu učenja, a shodno Bloomovoj taksonomiji obrazovnih ciljeva, nudi lista poželjnih glagola i lista glagola koje valja izbjegavati zbog nedovoljne određenosti, i to neovisno o tome radi li se o poučavanju u tehnologiji proizvodnje tijesta ili pak poučavanju u književnosti. Glagol »razumjeti«, koji je oduvijek bio u središtu humanističkog diskursa, smatra se tako nedovoljno preciznim i nepoželjnim. Ako se ishodi učenja ozbiljno shvate, tada se veliki dio energije 
učitelja rasipa na ispravan odabir pravog glagola za odgovarajuću rubriku razine i vrste učenja te udovoljavanje sve brojnijih zahtjeva općeg razrednog menadžmenta. Proklamirani nastavni ciljevi i precizno definirani i mjerljivi ishodi učenja, koji u formi aktivnih glagola otkrivaju što će sve učenici moći učiniti, neodoljivo podsjećaju na standardizirane uporabne deklaracije proizvoda. Riječju, instrumentalizacija škole više se ne očituje samo u potpunom podvrgavanju privrednim ciljevima, nego i sama škola postaje tvornica obučavanja.

Sve manje vremena, snage i resursa preostaje za imanentne zahtjeve proizašle iz posebnosti struka i njima primjerenog načina poučavanja, baš kao i za učiteljev razvoj, usavršavanje, dijalog i, razumljivo, nadzor njegova rada, ali prije svega u okvirima sadržajnih i metodičkih očekivanja i zahtjeva struke i sustručnjaka. Precizni i razlomljeni zahtjevi znanstvenog kurikula i općeg razrednog menadžmenta za mnoge su vrste učenja i poučavanja, osobito humanističkih znanosti, odveć invazivni, potkopavajući za spontanitet, radost učenja i poučavanja te naposljetku integritet učenika i autonomiju učitelja. Je li opća teorija znanstvenog upravljanja ili tzv. tejlorizam, ${ }^{12}$ koja uvećava produktivnost industrijskog rada s primjenom načela stroge podjele ili mrvljenja rada, njegove dekvalifikacije te apsolutne kontrole i optimalizacije izvedbe, ritma i očekivanih učinaka, doista izravno i bez ostataka primjenjiva u školi? Ili je nastavna komunikacija ipak složeniji sustav suodnošenja koji jednostranu apsolutizaciju kanona tehničke racionalnosti ne može podnijeti, a da ne odustane ili uvelike suzi druge, ne manje važne ciljeve odgoja i obrazovanja?

c) Treća vrsta redukcija koje donosi suvremeni znanstveno-tehnologijski i menadžerski koncept kurikula proizlazi iz njegovih eksplicitnih i implicitnih oslonaca u psihologijskoj teoriji radikalnog biheviorizma Burrhusa Frederica Skinnera. Riječ je o teorijskim i praktičkim osiromašenjima zbog toga što se

${ }^{12}$ Kovanica je stvorena prema velikom zagovorniku racionalne organizacije industrijske proizvodnje na temelju znanstvenih metoda upravljanja - inženjeru mehanike s početka 20. stoljeća Fredericku W. Tayloru. On je načela znanstvene organizacije proizvodnje: sistemsko planiranje, razlaganje na najjednostavnije pokrete i radnje, precizne upute, standardizacija i optimalizacija svakog koraka, koordinacija i kontrola, nastojao u okviru tzv. pokreta učinkovitosti u SAD početkom 20. stoljeća proširiti na socijalne, političke i osobne odnose. Jedan od prvih oblika opredmećenja principa tejlorizma je tzv. fordizam ili uvođenje radne tekuće trake u Fordovim tvornicama. Vidi: Taylor, 2010/1911. 
složenost odgojno-obrazovnih procesa, njegovih uloga i zahtjeva u cijelosti podvrgava pod jednostrane kanone radikalnog biheviorizma i njegovih dvojbenih metafizičkih, epistemoloških i antropologijskih pretpostavki, baš kao i kulturnih, socijalnih i političkih posljedica. Temeljni postulat radikalnog biheviorizma je stvoriti situaciju u kojoj je primjerena reakcija organizma na zahtjeve okoline pod kontrolom davatelja podražaja. Ta se strogo funkcionalna i upravljiva veza između podražaja odnosno potkrijepe i očekivanog poželjnog odgovora naziva operantno uvjetovanje. Jednostranost takvog modela učenja i oblikovanja ponašanja u znanstveno-tehnologijskom kurikulu ogleda se barem u dvije stvari:

1) podcjenjuju se mentalni procesi koji posreduju između potkrjepljivanja i djelatnog odgovora, odnosno zapostavljaju se uvidi kognitivističkih teorija i teorije socijalnog učenja. Neposredni rezultat toga je neopravdano zanemarivanje kompleksnih, dugoročnih i nemjerljivih dispozicija, sklonosti i kompetencija učenika.

2) učinkovitost i uvjerljivost operantnog uvjetovanja, odnosno radikalnog biheviorizma, očita je na razinama jednostavnih psihomotoričkih aktivnosti, dok s višim razinama učenja i poučavanja gubi na uvjerljivosti, posebice u humanističkom i društvenom predmetnom polju. ${ }^{13}$

O dvojbenim i najčešće neosviještenim pretpostavkama radikalnog biheviorizma, dovoljno je ovom prigodom sažeto istaknuti sljedeće: a) na metafizičkoj razini radikalni biheviorizam pretpostavlja reduktivni materijalizam i determinizam; b) na epistemološkoj razini ignoriraju se kognitivni procesi; c) na antropologijskoj razini podcjenjuje se posebnost i složenost čovjeka jer se rezultati laboratorijskih istraživanja na štakorima i golubovima nekritički i bez dovoljno posredovanja generaliziraju i projiciraju na ljudsko djelovanje. ${ }^{14}$

${ }^{13}$ Skinnerova metoda operantnog uvjetovanja najbolje rezultate pokazuje u posebnim ustanovama kao što su zatvori, specijalne odgojne ustanove, ustanove mentalnog zdravlja, vojske, tvornice. Usp. Watts, 1975.

${ }^{14}$ Skinner se dosljedno svojoj metodi razračunava s, po njegovu sudu, humanističkim iluzijama slobode i dostojanstva, kao i sa svim normativnim pojmovima: vrednota, ideala, namjera, nudeći tek ogoljenu sliku čovjeka kao nositelja reaktivnih funkcija. Vidi: Skinner, 1971. 
Ni konzekvence radikalnog biheviorizma nisu izuzete od prigovora. Na socijalnoj razini riječ je o prigovoru tehnologijske proizvodnje ljudskog ponašanja i socijalnog inženjeringa koji zapostavlja simboličku interakciju i komunikacijsku narav ljudskog djelovanja. Na političkoj razini konzekvence radikalnog biheviorizma su podcjenjivanje ljudske slobode, intencionalnosti, pluralizma vrednota i svjetonazora te posebnosti identiteta. ${ }^{15}$

Najizravnije posljedice znanstveno-tehnologijskog i menadžerskog koncepta kurikula očituju se u dvostrukoj - izvanjskoj ili ciljnoj i unutarnjoj ili izvedbenoj - bezostatnoj podređenosti odgoja i obrazovanja logici tržišnih potreba. Oponašanja modela isključivo instrumentalne racionalnosti i tehnologijskog procesa vodi k jednostranom apsolutiziranju izravne produktivnosti, površnih input-output analiza te fetišizaciji kratkoročnih koristi. To podrazumijeva i atomizaciju nastavnih ciljeva i sadržaja, njihovo jednoznačno i precizno definiranje podatno za mjerenja i kvantifikaciju, sveobuhvatni proceduralizam i uniformnost koji se ne obazire na različitost formi znanja i vještina. Čitav odgojnoobrazovni proces uokviren je s tri imperativa prvoga reda: optimalizacija performativnosti postupaka (Lyotard, 2005); bihevioristička redukcija znanja i kompetencija na funkcionalne vještine i empirijski mjerljive ishode; posvemašnja raspoloživost, modularnost i administrativna kontrola svakog koraka. Tome odgovora i plošna $3 T$ formula: targets - testing - tables koja zorno pokazuje svu uskoću Prokrustove postelje suvremenoga znanstveno-tehnologijskog i menadžerskog koncepta odgojno-obrazovnog kurikula. Razumljivo je da romantičarski koncept odgoja i obrazovanja posve odvojen od tržišnih zahtjeva danas jednostavno nije od ovoga svijeta. No istodobno je apsolutno legitimno i štoviše prijeko potrebno pitati gdje su i postoje li uopće granice između odgojno-obrazovnih i tržišnih potreba ili je odgoj i obrazovanje samo novoosvojeno polje tržišne ekspanzije, koja školu pretvara u tvornicu trenutačno utrživih sposobnosti i vještina.

\section{Zaključak}

Prednosti filozofskog pristupa u razmatranju odgojno-obrazovnog kurikula su kritička, holistička i dugoročna perspektiva s koje se vi-

${ }^{15} \mathrm{O}$ tome svjedoči i Skinnerova knjiga Walden Two koja u namjeri da pokaže prednosti socijalnog inženjeringa zapravo ocrtava dvojbenu utopijsku zajednicu sretnih ljudi u mekome totalitarizmu. Vidi: Skinner, 2005. 
šestruki i složeni normativni zahtjevi odgoja i obrazovanja mogu primjereno valorizirati. Odgoj i obrazovanje je, uostalom, temeljni čimbenik nematerijalne reprodukcije individualnog i socijalnog života, koji izgrađuje ljudski povijesni svijet jezika, značenja i vrednota. S druge strane, filozofija je, kako je to još davno ustvrdio John Dewey (Dewey, 1916), opća teorija odgoja utoliko što filozofijski uvidi čine i razvijaju naše vlastito povijesno samorazumijevanje - što mi jesmo, kako smo postali to što jesmo i kakvi bismo trebali biti?

Filozofski pristup kurikulu odgoja i obrazovanja razmatra njegove eksplicitne, implicitne i neosviještene pretpostavke o: a) svijetu, ljudskoj prirodi, biti i svrsi odgoja i obrazovanja te naravi učenja i poučavanja; b) logičko argumentacijskim i narativno-komunikacijskim uvjerljivostima kurikulnih koncepcija; c) posljedicama kurikulnih rješenja s obzirom na inherentne normativne zahtjeve odgoja i obrazovanja, ali i s obzirom na sveukupne kulturne, ekonomske, socijalne i političke aspekte zajedničkog života.

Suvremena kriza odgoja i obrazovanja prvenstveno je uvjetovana nekontroliranim širenjem logike kapitala, kao dominantnog društvenog i ekonomskog odnosa, na sve pore zajedničkog života. S prevlasti neposredovanih ekonomskih interesa dolazi do kljaštrenja i instrumentalizacije odgojno-obrazovnih zadaća.

Središnja rasprava filozofije odgoja u prošlome stoljeću bila je između tzv. progresivista, uključujući i kritički progresivizam ili eksperimentalizam Johna Deweya i, s druge strane, zagovornika tzv. liberalne teorije obrazovanja, kao što su R. S. Peters, Paul Hirst i Robert Dearden, koji na osobit način obnavljaju tradiciju artes liberales. Progresivisti u prvi plan postavljaju istraživalački koncept odgoja i obrazovanja, orijentaciju prema životnim i problemskim situacijama, ističu važnost interesa, integriteta i zadovoljstva učenika, dok zagovornici liberalne teorije bit odgoja i obrazovanja vidi u inicijaciji u temeljne i međusobno nesvodive forme znanja, koje razvijaju i strukturiraju mišljenje, sposobnosti i vještine. Obje struje, unatoč međusobnim razlikama u određenju ciljeva odgojno-obrazovnog procesa te načina njihova postignuća, ipak njeguju zajednički horizont u razumijevanja odgoja i obrazovanja omeđen vrednotama razvoja osobe, njezine slobode, autonomije i emancipacije. Obje su struje, nadalje, distancirane spram krutog instrumentalizma u odgoju i obrazovanju, koji, međutim, s procesima globalizacije postaje dominantna odgojno-obrazovna paradigma $u$ 
vidu znanstveno-tehnologijskoga i menadžerskog kurikula. Takva vrsta redukcije odgoja i obrazovanja na puko sredstvo za trenutačne tržišne ciljeve, središnji je problem odgojno-obrazovnih procesa današnjice. Primjereni odgovor na njega sigurno nije u moralizatorskom i manihejskom suprotstavljanju samosvrhovitosti odgoja i obrazovanja nasuprot njegovoj posvemašnjoj instrumentalizaciji. Odgovor je prije u traženju primjerene i razborite ravnoteže između prijeko potrebnih ekstrinzičnih ciljeva - ponajprije socijalizacije i ekonomskih zadaća, i intrinzičnih ciljeva - razvoja temeljnih sposobnosti za racionalnu autonomiju i samopoštovanje osobe na individualnom, socijalnom i političkom planu. Kazati da ovo posljednje nije neposredno korisno, kratkoročno iskazivo, mjerljivo, operabilno i isplativo, samo je naizgled istinito, ali zapravo svjedoči ne samo o dubokom nerazumijevanju naravi odgoja i obrazovanja nego i o duhu vremena koje s profilom homo oeconomicusa sve ljudske interese olako i nerazborito svodi na ekonomske.

Proces odgoja i obrazovanja ne podrazumijeva samo tehnički interes nadzora i kontrole nad prirodom i nama samima, koji onda stvara, svakako važne i potrebne, ekonomske potencijale. Odgoj i obrazovanje jednako tako uključuje, za ljudski način života prijeko potrebne, hermeneutičke interese refleksivnog i kritičkog samorazumijavanja te emancipacijske interese kultiviranja humaniteta (Habermas, 1975). Utoliko je prvi korak u stvaranju uspješnog kurikula pronalaženje primjerene i razborite ravnoteže između takvih mnogobrojnih i različitih zahtjeva i očekivanja. Filozofske refleksije, u svjetlu rasprava o reformi odgojno-obrazovnog sustava, mogu nam inicijalno pomoći na dvostruki način. Prvi je u osvještavanju zabluda i to: a) kako onih koje proizlaze iz nastojanja da se znanstveno-tehnologijski i menadžerski reducirani koncept obrazovanja predstavi kao napredak i emancipacija; tako i b) onih koje konzervativni, ili bilo koji drugi sveobuhvatni svjetonazor i tome pripadne supstancijalne vrednote, nastoje u naše suvremeno doba vrijednosnog pluralizma predstaviti kao univerzalni i emancipacijski humanizam. Drugi način smislenosti filozofske refleksije jest u kritičkom postavljanju standarda koji ne dopuštaju da se odgoj i obrazovanje olako svedu na puku obuku ili pak na ideologiju, nego da se shodno snažnom normativnom značenju odgoja i obrazovanja pristupi zadaćama kultiviranju uma i njegovanju humaniteta. 


\section{Literatura}

Bruner, Jerome (1977), The Process of Education, Cambridge, Massachusetts: Harvard University Press.

Bruner, Jerome (2000), Kultura obrazovanja, Zagreb: Educa.

Dewey, John (1916), Democracy and Education: An Introduction to the Philosophy of Education, New York: The MacMillan Company.

Giroux, Henry (1977), Pedagogy and the Politics of Hope, Oxford: Westview Press.

Giroux, Henry, (2005), Border Crossings: Cultural Workers and the Politics of Education, New York: Routledge.

Gutmann, Amy (1999), Democratic Education, Princeton: Princeton University Press.

[Habermas, Jürgen] Habermas, Jirgen (1975), Saznanje i interes, Beograd: Nolit.

Habermas, Jürgen (1978), »Čemu još filozofije?«, u: Brkić, Josip (ur.), Čemu još filozofija, Zagreb: Centar za kulturnu djelatnost SSO Zagreb.

Habermas, Jürgen (1986), »Prilog rekonstrukciji historijskog materijalizma«, u: Habermas, Jürgen, Tehnika i znanost kao »ideologija«, Zagreb: Školska knjiga, str. $140-186$.

Hirst, Paul H. (2010), Knowledge and the Curriculum: A Collection of Philosophical Papers, London: Routledge.

Kelly, Vic A. (2009), The Curriculum: Theory and Practice, London: Sage.

Kennedy, Declan (2006), Writing and Using Learning Outcomes: A Practical Guide, Cork: University College Cork.

Kliebard, Herbert (2004), The Struggle for the American Curriculum: 1983-1958, New York: Routledge.

Liessmann, Konrad Paul (2008), Teorija neobrazovanosti: Zablude društva znanja, Zagreb: Naklada Jesenski i Turk.

Lyotard, Jean-François (2005), Postmoderno stanje: Izvještaj o znanju, Zagreb: Ibis grafika.

[MZOS] Ministarstvo znanosti, obrazovanja i sporta RH (2011), Nacionalni okvirni kurikulum za predškolski odgoj i obrazovanje te opće obavezno $i$ srednjoškolsko obrazovanje, Zagreb: Ministarstvo znanosti, obrazovanja i sporta RH.

Peters, Richard S. (1978), Education and the Education of Teachers, London: Routledge.

Peters, Richard S. (2010) (ur.), The Concept of Education, London: Routledge.

Plessner, Helmuth (1981), Stupnjevi organskog i čovjek, Sarajevo: V. Masleša. 
Putnam, Hilary (2002), The Collapse of the Fact/Value Dichotomy, Cambridge, Massachusetts: Harvard University Press.

Putnam, Hilary; Putnam, Ruth Anna (1994), »Education for Democracy«, u: Putnam, Hilary (ur.), Words and Life, Cambridge, Massachusetts: Harvard University Press.

Raunić, Raul (1988), »Desubjektivizacija obrazovanja i treća tehnološka revolucija «, Naše teme, 32(1-2), str. 232-235.

Raunić, Raul (2011), Nacrt za prijedlog predmetnog kurikula filozofije, Zagreb: Hrvatsko filozofsko društvo, str. 1-14. Dostupno na:

http://www.hrfd.hr/documents/nacrt-predmetni-kurikulum-filozofije-rr-2.doc [21. 4. 2017.]

Rawls, John (1999), A Theory of Justice, Cambridge, Massachusetts: The Belknap Press of Harvard University Press.

Ryan, Alan (1988), »Deweyan Pragmatism and American Education«, u: Oksenberg Rorty, Amelie (ur.), Philosophers on Education, New York:Routledge, New York, str. 394-410.

Schön, Donald (1983), The Reflective Practitioner, New York: Basic Books.

Scott, David (2008), Critical Essays on Major Curriculum Theorists, New York: Routledge.

Skinner, Burrhus F. (1971), Beyond Freedom and Dignity, Harmondsworth: Penguin Books.

Skinner, Burrhus F. (2005), Walden Two, Indianopolis: Hackett Publishing Company.

Strawson, Peter F. (1999), Analiza i metafizika, Zagreb: KruZak.

Taylor, Frederick Winslow (2010/1911), The Principles of Scientific Management, New York: Cosimoclassics.

Watts, Merdith W. (1975), »B. F. Skinner and the technological control of social behaviour«, The American Political Science Review, 69(1), str. 214-227.

White, John (2010), The Aims of Education Restated, New York: Routledge.

Williams, Bernard (1985), Ethics and the Limits of Philosophy, London: Fontana Press.

Williams, Bernard (2002), Truth and Truthfulness: An Essay in Genealogy, Princeton: Princeton University Press. 


\section{PHILOSOPHY AND CURRICULUM}

\section{Raul Raunić}

This paper consists of three related series of arguments. First, it defines the basic descriptive and prescriptive meanings and the normative interrelatedness of the concepts of philosophy, the educational process, and the curriculum. Secondly, it analyses and criticizes the methodological structure of the dominant form of educational curriculum, based on the scientific-technological and managerial paradigm, instrumentally defined goals, and behaviourally validated and measurable learning outcomes. Finally, it explains the importance of philosophical reflection and a critical, holistic, long-term philosophical perspective to reflection on the educational curriculum. This importance manifests itself primarily in the identification of "blind alleys", which are those consisting only of instrumental goals and technological reductionisms on the one hand, and direct worldview parochialisms and exclusiveness on the other, which attempt to ideologically impose their particular substantive values as universal in today's world of value pluralism.

Key words: philosophical reflection, education: normative meaning and objectives, curriculum: history and theories, criticism of the scientifictechnological and managerial conception of curriculum 